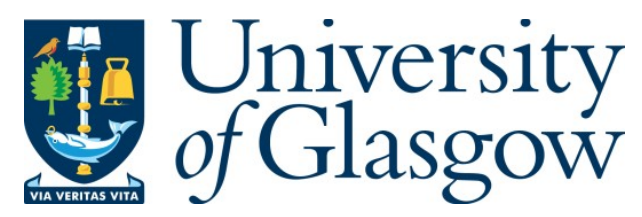

Mordi, I., Mordi, N., Delles, C., and Tzemos, N. (2016) Endothelial dysfunction in human essential hypertension. Journal of Hypertension, 34(8), pp. 1464-1472.

There may be differences between this version and the published version. You are advised to consult the publisher's version if you wish to cite from it.

$\underline{\text { http://eprints.gla.ac.uk/122566/ }}$

Deposited on: 04 October 2016

Enlighten - Research publications by members of the University of Glasgow http://eprints.gla.ac.uk 


\section{Endothelial Dysfunction in Human Essential Hypertension}

Ify Mordi ${ }^{1}$

Natalie Mordi $^{2}$

Christian Delles ${ }^{1}$

Nikolaos Tzemos ${ }^{1}$

1. Institute of Cardiovascular and Medical Sciences, University of Glasgow, Glasgow, United Kingdom, G12 8TA

2. Renal Unit, Queen Elizabeth University Hospital, Glasgow, United Kingdom, G51 4TF

Corresponding Author:

Dr Ify Mordi

Institute of Cardiovascular and Medical Sciences

British Heart Foundation Glasgow Cardiovascular Research Centre

University of Glasgow

Glasgow

United Kingdom

G12 8TA

E-mail: ifyrmordi@doctors.org.uk

Telephone: $+44(0) 1413302079$

Fax: +44(0)1413306697

Word Count 8,809 (including references)

We have no conflict of interest. 


\begin{abstract}
Although the endothelium has a number of important functions, the term endothelial dysfunction is commonly used to describe impairment in its vasodilatory capacity. It is increasingly recognised that this is related to hypertension, although whether it predates essential hypertension or is a consequence of it is still unknown. In this review we explore the mechanisms of endothelial dysfunction in essential hypertension, its prognostic significance and methods of pharmacological reversal.
\end{abstract}

Keywords: Endothelium; hypertension; ACE inhibitors 


\section{CONDENSED ABSTRACT}

Endothelial dysfunction is prevalent in hypertension and has a recognised association with the condition. In this article we review the pathophysiology of endothelial dysfunction in human essential hypertension, its prognostic significance and methods of pharmacological reversal. 
Essential hypertension is a worldwide epidemic, with approximately $20 \%$ of the world's population estimated to have a blood pressure greater than $140 / 90 \mathrm{mmHg}$, and accounting for around $10 \%$ of worldwide healthcare $\operatorname{costs}^{1,2}$. Due to its position as the leading risk factor for death worldwide, there is an increased drive towards its prevention ${ }^{3}$. Much of the adverse cardiovascular risk associated with hypertension is derived from its contribution to atherosclerosis, despite the two being distinct pathophysiological processes ${ }^{4}$.

Intuitively, the shared link between the two processes is the endothelium. Initially thought of as being a simple layer of cells in the vasculature separating blood from the interstitial space, it is now recognised as a key regulator of vascular health. Abnormalities in normal endothelial function are now recognised as a key part of both the atherosclerotic and hypertensive disease processes, sharing many common features.

Although the endothelium has a number of functions, the term "endothelial dysfunction" is usually used to refer to abnormalities in its vasodilatory capacity, and this is what we shall refer to in this paper. In this review we will discuss endothelial dysfunction, its links with hypertension and prognostic significance, before discussing treatment options and future direction.

\section{What is Endothelial Dysfunction?}

The endothelium responds to a number of endocrine, paracrine and autocrine signals to regulate these functions. The first evidence of this was described by Furchgott and Zawadzki who identified that the large blood vessels of rabbits only relaxed in response to acetylcholine if the endothelium was intact due to what they called endothelium-derived relaxing factor which we now know as nitric oxide $(\mathrm{NO})^{5}$. In fact, the endothelium releases a number of vasodilating and vasoconstricting factors with a local paracrine action. However, the healthy endothelium has a naturally vasodilated resting state, mainly due to the action of NO. NO is produced by the endothelium from L-arginine via the enzyme nitric oxide synthase in 
response to numerous factors including mechanical shear stress. NO passes into the underlying smooth muscle by diffusion, stimulating guanylate cyclase to cause increased cyclic GMP production and thus causing vasodilation ${ }^{6}$. NO has a number of vascular protective functions, impairment of which could have damaging cardiovascular consequences. It is a strong inhibitor of platelet aggregation and adhesion, giving it antiatherosclerotic properties. It also inhibits adhesion to leukocytes to the vessel wall and proliferation of vascular smooth muscle cells ${ }^{7}$. These features give the endothelium an important role in prevention of atherosclerosis development.

Any damage to the endothelium can cause impairment of its normal function i.e. endothelial dysfunction. This process is characterised by an imbalance in endothelium-dependent vasodilation and vasoconstriction and can occur by one of 3 methods.

1. Reduced production of NO; for example caused by reduced endothelial nitric oxide synthase (eNOS) activity due to asymmetric dimethylarginine (ADMA), a competitive inhibitor of $\mathrm{eNOS}^{8}$.

2. Reduced availability of NO; caused by reactive oxygen species (ROS) which convert NO to peroxynitrite which does not cause vasodilatation. ${ }^{9}$

3. Antagonism of NO by endothelium derived contracting factors. ${ }^{10}$

\section{Assessment of Endothelial Function}

Clinically endothelial function can be measured both invasively and non-invasively, and these have recently been reviewed in detail by Flammer et al. ${ }^{11} \mathrm{We}$ will briefly describe some of these techniques. 


\section{Invasive Assessment of Endothelial Function}

Invasive measurement of endothelial function can be conducted in the coronary arteries by quantitative angiography. This can be supplemented by intravascular ultrasound for more detailed assessment of the vasculature and intracoronary flow. ${ }^{12,13}$

Venous occlusion plethysmography is another commonly used technique for assessment of endothelial function. The technique can theoretically be performed in any vascular bed, but is most commonly performed in the forearm circulation, by cannulation of the brachial artery. ${ }^{14}$ Venous return in the forearm is prevented by inflation of a cuff to above venous pressure but below diastolic arterial pressure (e.g. $40 \mathrm{mmHg}$ ) with the forearm placed above the heart. The cuff is then deflated. A further cuff is inflated at the wrist to exclude the effects of the hand circulation. Changes in blood flow in the forearm can be measured using a plethysmograph. The concept relies on the concept that if (venous) blood flow out of the forearm is restricted but (arterial) inflow is maintained, the forearm swells at a rate in proportion to blood flow. As well as using plethysmography, ultrasound can also be used to measure arterial blood flow velocity and diameter (and hence flow).

Endothelial function can also be measured in the microvasculature. This is usually conducted by obtaining subcutaneous tissue biopsies, dissecting out small vessels and measuring function using micromyography (therefore it is an ex-vivo method to measure endothelial function). ${ }^{15}$ There have been varying results in studies correlating microvascular endothelial dysfunction and larger artery dysfunction, although this might be expected in different vascular beds. ${ }^{16-18}$

\section{Non-Invasive Assessment of Endothelial F unction}

The commonest non-invasive technique for evaluation of endothelial function currently in use involves brachial ultrasound during reactive hyperemia assessing flow mediated dilation (FMD). This involves interruption of blood flow in a peripheral artery (most commonly 
brachial) using a cuff to cause temporary ischemia. Release of the cuff causes an increase in blood flow and shear stress, leading to NO release and vasodilatation. The change in diameter of the blood vessel can be measured by ultrasound and is directly related to NO bioavailability, this providing a measure of endothelial function. ${ }^{19}$ This technique is particularly attractive as it is easy to repeat in patients, however there is still some variation between centres regarding image acquisition, for example in the time when measurements are obtained after cuff release so there still needs to be some standardization of the technique, though there have been attempts to do that. ${ }^{20,21}$ Recently, FMD has shown good, reproducible results in multi-centre studies when rigorous methodology is used, perhaps suggesting that it will soon be able to be utilised in large prospective population studies as an outcome measure. ${ }^{22,}{ }^{23}$ In a seven-centre study by Ghiadoni et al, the authors evaluated 135 adult healthy volunteers to assess reproducibility of FMD using a standardized protocol at 3 timepoints (baseline, 1 hour after baseline and 30 days after). They found that the technique was extremely reproducible across all sites, indicating that FMD could be used as a valid trial endpoint. ${ }^{22}$ These findings were extended in a further multi-centre study by Charakida et al who also evaluated patients up to 9 months after baseline FMD evaluation, and again the technique showed excellent reproducibility. ${ }^{23}$

Peripheral artery tonometry (PAT) is a technique that non-invasive assessment of vasomotor function by plethysmographically measuring changes in the fingertip pulse (most commonly) as a surrogate for arterial tone. Again, the endothelium-dependent response can be ascertained by reactive hyperaemia following arterial cuff occlusion. ${ }^{24}$

The cold pressor test was initially described in the 1930s by Hines and Brown. ${ }^{25}$ To summarise, the test involves the immersion of the patient's hand into a bowl of ice-cold water, which causes increased sympathetic activity, leading to peripheral vasodilatation and a rise in blood pressure. Additionally, this also causes coronary vasodilatation and an increase in myocardial blood flow in healthy patients. ${ }^{26}$ Therefore, using this technique, vascular 
endothelial function can be assessed in a number of ways. Non-invasive methods include measures of blood pressure, peripheral arterial diameter ${ }^{27}$ echocardiographic coronary artery diameter ${ }^{28}$ and techniques to evaluate myocardial blood flow such as $\mathrm{PET}^{26}$. Additionally, invasive techniques can be used to assess changes in coronary artery size during coronary artery catheterisation. ${ }^{29}$

More recently, laser Doppler has been utilised to measure endothelial function. This technique allows for non-invasive measurement of the microvasculature of the skin by assessing skin blood flow. ${ }^{30-32}$ This technique uses the backscatter provided by moving erythrocytes when they reflect a laser signal scanned across the skin. The erythrocytes reflect the signal back at a frequency proportional to their velocity hence blood flow can be measured.

\section{What is the Evidence for Endothelial Dysfunction in Hypertension - Cause or Effect?}

Demonstration of impaired endothelial dysfunction in hypertensive patients in the forearm resistance vessels was first reported, almost simultaneously in the early 90s, by Panza et al ${ }^{33}$ and Linder et al ${ }^{34}$ In the study by Panza et al, the authors studied changes in forearm blood flow in 18 hypertensive patients and 18 normotensive control subjects in response to acetylcholine and found that this response was impaired in the hypertensive patients. Linder et al evaluated 14 stable outpatients with essential hypertension (compared to 20 controls) and also found that the response to acetylcholine was blunted in hypertensives compared to controls. These findings have since been confirmed in patients with both essential and secondary hypertension..$^{35-38}$

For a long time it has been thought that hypertension caused endothelial dysfunction. Since the first study by Panza et al ${ }^{33}$ there have been numerous attempts to identify the mechanisms linking hypertension and endothelial dysfunction, however they are still not yet completely understood. There is a significant genetic component to the development of hypertension, and 
Taddei et al used this to try and identify a common pathway in the adult offspring of hypertensive patients ${ }^{39}$. In this study the authors found that the normotensive offspring of hypertensive patients had significantly impaired response to ACh in comparison to normotensive offspring of normotensive patients due to a defect in the L-arginine-NO pathway. Further evidence of a link between endothelial dysfunction and hypertension was obtained from the Framingham data ${ }^{40}$. In this study systolic blood pressure was significantly inversely correlated with FMD, although the design of the study did not allow for determination of causation. Another study found that the presence of elevated blood pressure in a cohort of Finnish teenagers was predictive of impaired FMD after 21 years of followup $^{41}$. Transient experimentally-induced hypertension has been shown to cause acute impairment of endothelial function in normotensive individuals ${ }^{42}$.

The mechanism of by which hypertension might cause endothelial dysfunction has been evaluated in various studies which have proposed a number of pathways, although many are in animals and of course caution is advised in extrapolation to human studies. Increased blood pressure causes an increase in superoxide production and a decrease in NO bioavailability ${ }^{9}$. A second mechanism involves the renin-angiotensin system. Angiotensin-converting enzyme (ACE) acts on the endothelium converting angiotensin I to angiotensin II. This causes vasoconstriction and also promotes production of endothelin, another potent vasoconstrictor. An increase in both of these vasoactive substances manifests as endothelial dysfunction ${ }^{44}$. However, the adverse prognostic effects of angiotensin II are not purely due to vasoconstriction. Indeed, hypertensive patients tend to have similar levels of plasma angiotensin to normotensives ${ }^{45}$. In fact, angiotensin II also stimulates production of superoxide which leads to peroxynitrite formation. Peroxynitrite oxidizes arachidonic acid to form isoprostane, a potent vasoconstrictor.

The hypothesis that hypertension is a consequence of endothelial dysfunction has also been explored. A dysfunctional endothelium with poor vasomotor function would be in a state of 
predominant vasoconstriction leading to a higher resting blood pressure. In one of the largest studies to date, Rossi et al examined 952 post-menopausal normotensive women and found that the risk of development of hypertension over the 3.6-year follow-up period was significantly higher in patients with low FMD compared with those with the highest at baseline. ${ }^{46}$ This was however a study in a low-risk population in women and it is not clear if these results can be extrapolated to higher risk populations and males. Another recent study by Weil et al suggested that individuals with "pre-hypertension" (defined as BP 120-139/8089) also had impaired endothelium-dependent vasodilation, which the authors speculated might lead to the development of hypertension. ${ }^{47}$

It is likely that the relationship between endothelial dysfunction and hypertension is not sequential, but rather a cyclical one. Worsening in one may lead to worsening in the other, in a "vicious cycle" effect. Therefore, it could be important to establish its prognostic significance, if any, and consider treatment options.

\section{The Prognostic Significance of Endothelial Dysfunction in Hypertension}

Endothelial dysfunction has been shown to be an adverse prognostic indicator in several studies, for example in patients with coronary artery disease $e^{48,49}$, heart failure ${ }^{50,51}$ and peripheral vascular disease ${ }^{52}$. Fewer studies have been conducted specifically in hypertension however. One of the earliest studies investigating the prognostic value of endothelial dysfunction in hypertension was carried out by Perticone et al. ${ }^{53}$ In this study the authors examined 225 patients with untreated hypertension and found that the only independent predictors of future cardiovascular events were mean 24-hour blood pressure and endothelial dysfunction measured by forearm blood flow response using FMD. Hypertensive patients who have shown an improvement in endothelial function following intensive antihypertensive treatment also appear to have a better outcome than those in whom endothelial function does not improve ${ }^{54}$ Despite these promising early studies there have been no other large trials replicating these results. Some doubts about the generalizability of the study by Perticone et 
al. could be raised, particularly regarding the surprisingly high event rate for what would be expected to be a low-risk population (4.9\%/year). Indeed, conflicting results to these have been found in one smaller study ${ }_{.5}^{55}$ All in all, it has not yet been established that endothelial dysfunction can be used as a predictor of adverse cardiovascular outcome in hypertensive patients, despite the evidence for its existence.

\section{Pharmacological Reversal of Endothelial Dysfunction in Hypertension}

Given the potential prognostic significance of endothelial dysfunction in hypertension, many studies have been conducted to improve endothelial function in this group of patients. The obvious starting point is with anti-hypertensive therapy. All of the mainstays of antihypertensive therapy have been extensively studied.

\section{The Renin-Angiotensin-Aldosterone System}

The majority of work has been conducted in drugs affecting the renin-angiotensin-aldosterone system. Angiotensin II stimulates angiotensin type 1 receptors $\left(\mathrm{AT}_{1}\right)$ to mediate arteriolar vasoconstriction and remodelling, superoxide anion production, renal sodium reabsorption, aldosterone secretion and endothelin (ET-1) release. ${ }^{56}$ Many of these actions affect the vascular endothelium adversely. On the other hand stimulation of the angiotensin type 2 $\left(\mathrm{AT}_{2}\right)$ receptor by angiotensin has mainly opposing actions to those of $\mathrm{AT}_{1}$ stimulation and recently has been shown to contribute to endothelial $\mathrm{NO}$ release. ${ }^{57}$ Hence, $\mathrm{AT}_{1}$ receptor blockade could improve NO bioactivity.

Angiotensin II can be reduced by angiotensin converting enzyme inhibitors which also increase both tissue and plasma bradykinin by inhibiting kininase II. ${ }^{58}$ By stimulating the B2 receptors, bradykinin mediates the release of NO, prostacyclin and the endothelial hyperpolarizing factor (EDHF); agents that produce vasodilation. ${ }^{59-61}$ ACE-Is (angiotensin converting enzyme inhibitors) and ARBs (angiotensin receptor blockers) are among the firstline therapies for hypertension. ${ }^{62}$ Two large studies have investigated the effects of ACE-Is 
and ARBs in the coronary and forearm vasculature (TREND, BANFF) respectively in patients with atherosclerosis, showing improvement in endothelial function. ${ }^{63,}{ }^{64}$ Several studies have confirmed this beneficial effect in hypertensive patients. Two independent longterm studies evaluating respectively the vascular responses to cilazapril and lisinopril on subcutaneous arteries (small resistance vessels) in essential hypertensives showed a considerable improvement in stimulated NO release following prolonged treatment with these agents. ${ }^{65,66}$ Similar results were obtained in the coronary microcirculation of hypertensive patients with ACE-I. Antony et al showed that intravenous perindoprilat (the active metabolite of perindopril) restored the cold pressor test response and flow-mediated coronary artery vasodilation in 10 patients with untreated (newly diagnosed) essential hypertension. ${ }^{67}$. Taddei et al have reported that 1 year of treatment with lisinopril improved endotheliumdependent and independent vasodilatation in forearm vasculature of hypertensives ${ }^{68}$ Several other studies also report improvement in endothelial function following ACE inhibition. ${ }^{69-73}$ However, there have also been studies have showing conflicting results. ${ }^{74,75}$

There are also reports of the beneficial effects of ARBs on endothelial function. Schiffrin et al reported that one year of treatment with losartan improved both functional and structural properties of small resistance (subcutaneous) arteries in hypertensive patients. ${ }^{76}$ Ghiadoni et al found that 1 year of treatment with candesartan improved stimulated NO release, but this was accompanied by a concomitant endothelium-independent improvement suggesting an alteration in vascular smooth muscle cell responsiveness. ${ }^{77}$ Tzemos et al also found that valsartan mediated an improvement in endothelial function through both NO-dependent and independent pathways. ${ }^{78}$ This is slightly contrary to a study by Klingbeil et al who found that while valsartan causes an increase in nitric oxide production in hypertensives there was no improvement in $\mathrm{ACh}$ mediated vasodilatation. ${ }^{79}$ The authors postulated that the changes in $\mathrm{ACh}$ mediated vasodilatation may take longer to occur in hypertension and therefore require a longer period of treatment (the patients in this study were treated for 6 weeks as opposed to 
16 weeks in the study by Tzemos et al.). Further studies have also shown beneficial effects on endothelial function with ARBs. ${ }^{80}$

In summary, blocking the renin-angiotensin-aldosterone system either at the conversion from angiotensin I to II or at the angiotensin II receptor level may favourably affect NO bioactivity. It is likely that in the forearm microcirculation the tissue renin-angiotensin system is the predominant generator of angiotensin II hence only ACE-Is with high tissue penetration (enough to block the tissue renin-angiotensin system) are likely to be effective ${ }^{63,81}$. In a subanalysis of the recent EUROPA study (examining the beneficial effects of ACE-inhibition in patients with stable coronary artery disease), perindopril appeared to increase expression and activity of eNOS by $19 \%$ and $27 \%$ respectively, as well as a significant reduction in plasma levels of angiotensin II, tumour necrosis factor- $\alpha$ and an increase in bradykinin, nitrate and nitrite ${ }^{82}$.

In summary, it would appear that of ACEIs and ARBs overall have beneficial effects on endothelial function. ${ }^{83-87}$

Spironolactone and eplerenone, mineralocorticoid receptor antagonists, have received much attention recently. They are recommended as $3^{\text {rd }}$ or $4^{\text {th }}$ line therapy in hypertension. ${ }^{62}$ They have been reported to improve NO bioactivity in patients with heart failure. ${ }^{88}$ The mechanism(s) by which aldosterone impairs endothelial function is unclear. Aldosterone it is known to enhance vascular responsiveness to pressor agents such as norepinephrine and angiotensin II even before the systemic blood pressure begins to increase ${ }^{89}$ In patients with secondary hypertension due to aldosterone producing adrenal adenomas, surgical excision of these tumours removed the excess circulating aldosterone resulting in a normalised acetylcholine vascular response, i.e. improved endothelial function and BP control..$^{90}$ 
While there have been several animal studies showing beneficial effects of aldosterone blockade $^{91-94}$, there have been fewer in humans and results have been mixed. Savoia et al ${ }^{95}$ conducted a randomised controlled trial comparing eplerenone to atenolol in 16 patients for 1 year and concluded that eplerenone treatment was associated with reduced arterial stiffness, decreased collagen/elastin ratio, and a reduction in circulating inflammatory mediators. While the study by Savoia et al and one by Yamanari et al ${ }^{96}$ did not show that this improvement in endothelial function with aldosterone antagonists translated to humans, a more recent study by Fujimura did find an improvement in FMD with eplerenone ${ }^{97}$. A further study in 320 postmenopausal women with hypertension by Rossi et al reported that use of aldosterone receptor antagonists (in conjunction with routine anti-hypertensive therapy) was the only drug class independently associated with improvement in FMD after 6 months. ${ }^{98}$

Aliskiren, a novel direct renin inhibitor, has been recently studied in humans by Virdis in a comparative study against ramipril. ${ }^{99}$ Aliskiren produced a significantly greater reduction in augmentation index and improved the vasodilatory response to acetylcholine, however blood pressure and pulse wave velocity reduction was the same in both groups. Dorresteijn et al also suggest that aliskiren may provide benefits in endothelial function in comparison to moxonidine or hydrochlorothiazide. ${ }^{100}$ These results may provide interesting directions for further research, although aliskiren cannot as yet be recommended as anti-hypertensive therapy.

\section{Dihydropyridine Calcium Channel Blockers}

These are also recommended as first-line antihypertensive therapies. ${ }^{62}$ Calcium channel blockers (CCBs) have been shown to have a beneficial effect on nitric oxide bioactivity in coronary, forearm and resistance (subcutaneous) vascular beds. ${ }^{71}$ Perticone et al showed that oral isradipine also improved both stimulated (ACh-induced) and basal NO release in hypertension. ${ }^{101}$ Taddei et al demonstrated contrasting effects on the endothelium with acute and chronic administration of a highly lipophilic CCB, lacidipine. ${ }^{102}$ This group showed that 
intra-arterial lacidipine did not significantly affect acute NO bioactivity, but chronic ( 2 and 8 months) oral treatment with this agent significantly increased vasodilatation in response to acetylcholine and bradykinin compared to baseline. Interestingly, this improvement in endothelial function persisted 2 weeks after drug withdrawal, despite the patients returning to hypertensive state. This suggests that improvement in endothelial function may be separate to blood pressure control, or that the effects of medications on each may have different durations. Similar improvements in endothelial function have been seen in other studies also. ${ }^{103,104}$

The mechanism by which CCBs improve endothelial dysfunction is unclear, although several mechanisms have been postulated. CCBs act directly on voltage dependent L-type calcium channels found on the vascular smooth muscle cells. Blockade of these channels reduces the influx of extracellular calcium into the sarcoplasmic reticulum facilitating vascular smooth muscle cell relaxation. However, endothelial cells are devoid of these receptors for calcium channel blockers to act on. In the coronary microcirculation the addition of a calcium channel blocker appears to indirectly facilitate an increase in intracellular smooth muscle cell cGMP, which is the second messenger of NO and mediates its vasodilation. Therefore, as expected an increase in intracellular cGMP with calcium channel blockers enhances both endothelium dependent and independent vasodilation. ${ }^{105,} 106$ This has been confirmed with both dihydropyridine and non-dihydropyridine calcium channel blockers. In contrast, in the forearm microcirculation, calcium channel blockers do not appear to influence the NOindependent pathway whenever exogenous organic sources of NO such as nitrates ${ }^{107}$ are present.

Two additional mechanisms have been described to explain the effects of calcium channel blockers in the forearm circulation. The first explanation is that most calcium channel blockers have antioxidant activities, reducing production of superoxide anions. ${ }^{88,}{ }^{89}$ The second explanation involves a reduction in endothelin-1 release by calcium channel blockers. 
Normally, there is a balance between vasoconstrictive and vasodilating substances in the vasculature but in hypertension, the bioavailability of endothelin might be increased in parallel with a reduction in NO bioactivity. Cardillo et al have recently shown that in patients with essential hypertension, the increased endothelin activity is partly responsible for the increased vascular tone. ${ }^{108}$ It has been shown that calcium channel blockers improve NO bioactivity by reducing endothelin release. ${ }^{100,}{ }^{101}$ Hence, in a model where vasoconstrictive activity is increased, such as hypertension, a reduction of endothelin release would improve NO bioactivity. CCBs may also improve other aspects of endothelial dysfunction, e.g. reducing tissue plasminogen activator activity, thus reducing thrombogenic risk by decreasing platelet activation. ${ }^{109}$

\section{Diuretics and Beta-blockers}

Diuretics (specifically thiazides) are mainstays of anti-hypertensive therapy, and although beta-blockers are now no longer first-line for hypertension, they remain widely prescribed in hypertensive patients, particularly in those with concomitant conditions such as angina. However, despite the efficacy of both classes of drugs in improving overall prognosis in hypertension, neither has been consistently shown to significantly improve endothelial function. ${ }^{73,76,110-113}$ One exception is nebivolol, a highly selective $\beta 1$-blocker that has been shown to improve endothelial dysfunction both in vivo and vitro. ${ }^{114,115}$ Dawes et al reported that acute intra-arterial administration of nebivolol improved forearm vasculature NO bioactivity in hypertensive patients. Although the mechanism by which nebivolol improves endothelial function in hypertension is not yet fully elucidated a putative pharmacological cross-reactivity between serotonin and $\beta$-receptors might potentially explain these vascular effects. ${ }^{116,117}$ A possible antioxidant property of nebivolol has been suggested as an additional factor increasing NO-bioactivity or even a reduction in endothelin (ET-1) release. ${ }^{118,119}$ The beneficial effects of nebivolol on the endothelium were confirmed in humans by Tzemos et

al. ${ }^{120}$ In a double-blind crossover trial, 12 hypertensive patients were given 8 weeks of treatment with bendroflumethiazide plus atenolol or nebivolol (and then switched to the other 
group). With both treatments the blood pressure reduction was the same, however there was a significant increase in both forearm vasodilatory response to acetylcholine and the vasoconstrictor response to L-NMMA, suggesting that there may be a beneficial effect of nebivolol beyond blood pressure reduction. The endothelial effects of nebivolol are unique amongst beta-blockers and have been replicated in other studies. ${ }^{121,122}$ Recent work by Vitale et al has suggested that nebivolol in combination with hydrochlorthiazide might at least be non-inferior to irbesartan with hydrochlorthiazide, perhaps giving some hope to beta-blockers in hypertension. ${ }^{123}$ Indeed, a recent meta-analysis of 1,273 patients from 16 studies by Peller et al. on the effects of beta-blockers on endothelial function in various groups of patients did shown some benefit, however the study did include somewhat homogenous groups of patients. ${ }^{124}$ The authors did find, consistent with studies in hypertension, that the best improvement in endothelial function was seen with $3^{\text {rd }}$ generation beta-blockers such as nebivolol.

There have been some small studies suggesting that thiazide (and thiazide-like) diuretics might improve endothelial function. Some studies have shown that indapamide may also improve endothelial function in hypertensive patients when used in combination with ACE inhibitors. ${ }^{125,126}$ Chlortalidone has also been shown to improve endothelial dysfunction in hypertensive patients. ${ }^{127}$ The beneficial effects shown in these relatively small studies have yet to be confirmed in larger trials, particularly studies focussing on cardiovascular outcomes.

\section{Endothelin Receptor Antagonists}

Endothelin 1 (ET-1) acting through the ETA receptor is a potent vasoconstrictor that also promotes vascular smooth muscle cell proliferation. ${ }^{128,129}$ Its expression in the vessel wall is promoted by ATII, and its vasoconstrictive effect appears to be enhanced in hypertensives. ${ }^{107}$, 130, 131 However, the plasma levels of ET-1 have not been consistently found to be raised in hypertension. ${ }^{132,133}$ Nonetheless, ET-1 is released abluminally rather luminally, hence its plasma levels may not necessarily reflect its activity. ${ }^{134}$ Increased ET-1 activity has been 
found in salt-sensitive hypertension. ${ }^{135,136}$ In human hypertension, Cardillo et al have shown that forearm intrabrachial administration of both selective and non-selective endothelin receptor blockers improved endothelium-dependent vasodilation. ${ }^{108}$ The vasodilating properties of endothelin-1 receptor blockers might explain the beneficial effects on BP of bosentan, a non-selective ET-1 receptor blocker. Krum et al have shown that 4 weeks of treatment with bosentan reduced blood pressure as effectively as enalapril. ${ }^{137}$ Moreover, the favourable effect of treatment with bosentan on blood pressure occurred without reflexive neurohormonal activation, which may suggest a more targeted effect of this drug on endothelial ET-1. Atrasentan (a selective ET-1 subtype A receptor antagonist) has also been shown to improve coronary endothelial function. ${ }^{138}$

\section{Future Directions and Conclusions}

There is little doubt that endothelial dysfunction and hypertension co-exist, however many questions still need to be answered. While we know that reducing blood pressure improves prognosis, there is still a lot doubt as to the incremental prognostic value of measurement of endothelial function. If this is established, we then need to find therapies that can improve endothelial function and whether this can translate to a longer-term prognostic benefit. The measurement of endothelial function itself needs to be standardized further and validated so that it can be used as both an endpoint in prognostic studies and as a marker in general clinical use. In common with much of the literature in this area, we have used the term "endothelial dysfunction" to refer exclusively to the vasodilatory properties of the endothelium, however it has numerous other functions, many of which could be quantified such as platelet aggregation and inflammation, and might have prognostic significance and may offer new therapeutic targets.

Endothelial dysfunction is associated with hypertension and its presence correlates with target organ damage. Furthermore, endothelial dysfunction may be both a cause and a consequence of hypertension. In this review, we have discussed the pathways by which endothelial 
dysfunction may occur and the clinical evidence of its importance. Finally, we discussed the evidence looking at reversal of endothelial function, both by non-pharmacological methods and antihypertensive medications and therapies more directly targeted at the endothelium. Antihypertensive drug treatment improves and in some cases reverses endothelial dysfunction but this appear to depend very much on drug class and the vascular territories studied. Although calcium channel blockers, ACE-I, and ARBs seem to outperform beta-blockers (with the exception of nebivolol) and diuretics in terms of improving endothelial dysfunction, they do not seem to produce a greater antihypertensive effect. Most importantly, there is still some doubt within the scientific community as to whether the improvement in endothelial function is translated into long-term prognostic benefit.

In conclusion, although endothelial dysfunction is a conceptually attractive therapeutic target in hypertension, at this point in time, we lack convincing data that using endothelial dysfunction to guide our treatment would produce any better outcomes than using blood pressure targets to guide our treatment. This situation may change in the near future as more trials are conducted in this area. 


\section{REFERENCES}

1. Brundtland GH. From the world health organization. Reducing risks to health, promoting healthy life. JAMA. 2002;288:1974

2. Gaziano TA, Bitton A, Anand S, Weinstein MC. The global cost of nonoptimal blood pressure. J Hypertens. 2009;27:1472-1477

3. Lawes CM, Vander Hoorn S, Rodgers A. Global burden of blood-pressure-related disease, 2001. Lancet. 2008;371:1513-1518

4. Alexander RW. Theodore cooper memorial lecture. Hypertension and the pathogenesis of atherosclerosis. Oxidative stress and the mediation of arterial inflammatory response: A new perspective. Hypertension. 1995;25:155-161

5. Furchgott RF, Zawadzki JV. The obligatory role of endothelial cells in the relaxation of arterial smooth muscle by acetylcholine. Nature. 1980;288:373-376

6. Murad F. The nitric oxide-cyclic gmp signal transduction system for intracellular and intercellular communication. Recent Prog Horm Res. 1994;49:239-248

7. Forstermann U, Munzel T. Endothelial nitric oxide synthase in vascular disease: From marvel to menace. Circulation. 2006;113:1708-1714

8. Kielstein JT, Bode-Boger SM, Frolich JC, Ritz E, Haller H, Fliser D. Asymmetric dimethylarginine, blood pressure, and renal perfusion in elderly subjects. Circulation. $2003 ; 107: 1891-1895$

9. Rubanyi GM, Vanhoutte PM. Superoxide anions and hyperoxia inactivate endothelium-derived relaxing factor. Am J Physiol. 1986;250:H822-827

10. Luscher TF, Boulanger CM, Dohi Y, Yang ZH. Endothelium-derived contracting factors. Hypertension. 1992;19:117-130

11. Flammer AJ, Anderson T, Celermajer DS, Creager MA, Deanfield J, Ganz P, et al. The assessment of endothelial function: From research into clinical practice. Circulation. 2012;126:753-767 
12. Celermajer DS. Endothelial dysfunction: Does it matter? Is it reversible? J Am Coll Cardiol. 1997;30:325-333

13. Ludmer PL, Selwyn AP, Shook TL, Wayne RR, Mudge GH, Alexander RW, Ganz P. Paradoxical vasoconstriction induced by acetylcholine in atherosclerotic coronary arteries. N Engl J Med. 1986;315:1046-1051

14. Wilkinson IB, Webb DJ. Venous occlusion plethysmography in cardiovascular research: Methodology and clinical applications. Br J Clin Pharmacol. 2001;52:631646

15. Deanfield J, Donald A, Ferri C, Giannattasio C, Halcox J, Halligan S, et al. Endothelial function and dysfunction. Part i: Methodological issues for assessment in the different vascular beds: A statement by the working group on endothelin and endothelial factors of the european society of hypertension. J Hypertens. 2005;23:717

16. Park JB, Charbonneau F, Schiffrin EL. Correlation of endothelial function in large and small arteries in human essential hypertension. J Hypertens. 2001;19:415-420

17. van Hecke MV, Dekker JM, Nijpels G, Stolk RP, Henry RM, Heine RJ, et al. Are retinal microvascular abnormalities associated with large artery endothelial dysfunction and intima-media thickness? The hoorn study. Clin Sci (Lond). 2006; 110:597-604

18. Virdis A, Taddei S. How to evaluate microvascular organ damage in hypertension: Assessment of endothelial function. High Blood Press Cardiovasc Prev. 2011;18:163-167

19. Kuvin JT, Karas RH. Clinical utility of endothelial function testing: Ready for prime time? Circulation. 2003;107:3243-3247

20. Charakida M, Masi S, Luscher TF, Kastelein JJ, Deanfield JE. Assessment of atherosclerosis: The role of flow-mediated dilatation. Eur Heart J. 2010;31:28542861 
21. Corretti MC, Anderson TJ, Benjamin EJ, Celermajer D, Charbonneau F, Creager MA, et al. Guidelines for the ultrasound assessment of endothelial-dependent flowmediated vasodilation of the brachial artery: A report of the international brachial artery reactivity task force. J Am Coll Cardiol. 2002;39:257-265

22. Ghiadoni L, Faita F, Salvetti M, Cordiano C, Biggi A, Puato M, et al. Assessment of flow-mediated dilation reproducibility: A nationwide multicenter study. J Hypertens. 2012;30:1399-1405

23. Charakida M, de Groot E, Loukogeorgakis SP, Khan T, Luscher T, Kastelein JJ, et al. Variability and reproducibility of flow-mediated dilatation in a multicentre clinical trial. Eur Heart J. 2013;34:3501-3507

24. Hamburg NM, Keyes MJ, Larson MG, Vasan RS, Schnabel R, Pryde MM, et al. Cross-sectional relations of digital vascular function to cardiovascular risk factors in the framingham heart study. Circulation. 2008;117:2467-2474

25. Wood DL, Sheps SG, Elveback LR, Schirger A. Cold pressor test as a predictor of hypertension. Hypertension. 1984;6:301-306

26. Siegrist PT, Gaemperli O, Koepfli P, Schepis T, Namdar M, Valenta I, et al. Repeatability of cold pressor test-induced flow increase assessed with $\mathrm{h}(2)(15) \mathrm{o}$ and pet. J Nucl Med. 2006;47:1420-1426

27. Corretti MC, Plotnick GD, Vogel RA. The effects of age and gender on brachial artery endothelium-dependent vasoactivity are stimulus-dependent. Clin Cardiol. $1995 ; 18: 471-476$

28. Deng YB, Wang XF, Li CL. A new noninvasive method for evaluation of coronary endothelial function in hypertensive patients based on change in diameter of the left main coronary artery induced by cold pressor test using echocardiography. Clin Cardiol. 2001;24:291-296

29. Nitenberg A, Chemla D, Antony I. Epicardial coronary artery constriction to cold pressor test is predictive of cardiovascular events in hypertensive patients with 
angiographically normal coronary arteries and without other major coronary risk factor. Atherosclerosis. 2004;173:115-123

30. Roustit M, Millet C, Blaise S, Dufournet B, Cracowski JL. Excellent reproducibility of laser speckle contrast imaging to assess skin microvascular reactivity. Microvasc Res. 2010;80:505-511

31. Roustit M, Cracowski JL. Non-invasive assessment of skin microvascular function in humans: An insight into methods. Microcirculation. 2012;19:47-64

32. Turner J, Belch JJ, Khan F. Current concepts in assessment of microvascular endothelial function using laser doppler imaging and iontophoresis. Trends Cardiovasc Med. 2008;18:109-116

33. Panza JA, Quyyumi AA, Brush JE, Jr., Epstein SE. Abnormal endotheliumdependent vascular relaxation in patients with essential hypertension. $N$ Engl J Med. $1990 ; 323: 22-27$

34. Linder L, Kiowski W, Buhler FR, Luscher TF. Indirect evidence for release of endothelium-derived relaxing factor in human forearm circulation in vivo. Blunted response in essential hypertension. Circulation. 1990;81:1762-1767

35. Karthikeyan VJ, Blann AD, Baghdadi S, Lane DA, Gareth Beevers D, Lip GY. Endothelial dysfunction in hypertension in pregnancy: Associations between circulating endothelial cells, circulating progenitor cells and plasma von willebrand factor. Clin Res Cardiol. 2011;100:531-537

36. Panza JA, Casino PR, Kilcoyne CM, Quyyumi AA. Impaired endothelium-dependent vasodilation in patients with essential hypertension: Evidence that the abnormality is not at the muscarinic receptor level. J Am Coll Cardiol. 1994;23:1610-1616

37. Panza JA, Garcia CE, Kilcoyne CM, Quyyumi AA, Cannon RO, 3rd. Impaired endothelium-dependent vasodilation in patients with essential hypertension. Evidence that nitric oxide abnormality is not localized to a single signal transduction pathway. Circulation. 1995;91:1732-1738 
38. Taddei S, Virdis A, Mattei P, Salvetti A. Vasodilation to acetylcholine in primary and secondary forms of human hypertension. Hypertension. 1993;21:929-933

39. Taddei S, Virdis A, Mattei P, Ghiadoni L, Sudano I, Salvetti A. Defective 1-argininenitric oxide pathway in offspring of essential hypertensive patients. Circulation. $1996 ; 94: 1298-1303$

40. Benjamin EJ, Larson MG, Keyes MJ, Mitchell GF, Vasan RS, Keaney JF, Jr., et al. Clinical correlates and heritability of flow-mediated dilation in the community: The framingham heart study. Circulation. 2004;109:613-619

41. Juonala M, Viikari JS, Ronnemaa T, Helenius H, Taittonen L, Raitakari OT. Elevated blood pressure in adolescent boys predicts endothelial dysfunction: The cardiovascular risk in young finns study. Hypertension. 2006;48:424-430

42. Millgard J, Lind L. Acute hypertension impairs endothelium-dependent vasodilation. Clin Sci (Lond). 1998;94:601-607

43. Gryglewski RJ, Palmer RM, Moncada S. Superoxide anion is involved in the breakdown of endothelium-derived vascular relaxing factor. Nature. 1986;320:454456

44. Luscher TF. Endothelial dysfunction: The role and impact of the renin-angiotensin system. Heart. 2000;84 Suppl 1:i20-22:discussion i50

45. Romero JC, Reckelhoff JF. State-of-the-art lecture. Role of angiotensin and oxidative stress in essential hypertension. Hypertension. 1999;34:943-949

46. Rossi R, Chiurlia E, Nuzzo A, Cioni E, Origliani G, Modena MG. Flow-mediated vasodilation and the risk of developing hypertension in healthy postmenopausal women. J Am Coll Cardiol. 2004;44:1636-1640

47. Weil BR, Stauffer BL, Greiner JJ, DeSouza CA. Prehypertension is associated with impaired nitric oxide-mediated endothelium-dependent vasodilation in sedentary adults. Am J Hypertens. 2011;24:976-981 
48. Suwaidi JA, Hamasaki S, Higano ST, Nishimura RA, Holmes DR, Jr., Lerman A. Long-term follow-up of patients with mild coronary artery disease and endothelial dysfunction. Circulation. 2000;101:948-954

49. Halcox JP, Schenke WH, Zalos G, Mincemoyer R, Prasad A, Waclawiw MA, et al. Prognostic value of coronary vascular endothelial dysfunction. Circulation. $2002 ; 106: 653-658$

50. Fischer D, Rossa S, Landmesser U, Spiekermann S, Engberding N, Hornig B, Drexler H. Endothelial dysfunction in patients with chronic heart failure is independently associated with increased incidence of hospitalization, cardiac transplantation, or death. Eur Heart J. 2005;26:65-69

51. Akiyama E, Sugiyama S, Matsuzawa Y, Konishi M, Suzuki H, Nozaki T, et al. Incremental prognostic significance of peripheral endothelial dysfunction in patients with heart failure with normal left ventricular ejection fraction. J Am Coll Cardiol. 2012;60:1778-1786

52. Gokce N, Keaney JF, Jr., Hunter LM, Watkins MT, Nedeljkovic ZS, Menzoian JO, Vita JA. Predictive value of noninvasively determined endothelial dysfunction for long-term cardiovascular events in patients with peripheral vascular disease. $J$ Am Coll Cardiol. 2003;41:1769-1775

53. Perticone F, Ceravolo R, Pujia A, Ventura G, Iacopino S, Scozzafava A, et al. Prognostic significance of endothelial dysfunction in hypertensive patients. Circulation. 2001;104:191-196

54. Modena MG, Bonetti L, Coppi F, Bursi F, Rossi R. Prognostic role of reversible endothelial dysfunction in hypertensive postmenopausal women. J Am Coll Cardiol. $2002 ; 40: 505-510$

55. Rizzoni D, Porteri E, De Ciuceis C, Boari GE, Zani F, Miclini M, et al. Lack of prognostic role of endothelial dysfunction in subcutaneous small resistance arteries of hypertensive patients. J Hypertens. 2006;24:867-873 
56. Dzau VJ. Local expression and pathophysiological role of renin-angiotensin in the blood vessels and heart. Basic Res Cardiol. 1993;88 Suppl 1:1-14

57. Siragy HM, de Gasparo M, Carey RM. Angiotensin type 2 receptor mediates valsartan-induced hypotension in conscious rats. Hypertension. 2000;35:1074-1077

58. Erdos EG. The angiotensin i converting enzyme. Fed Proc. 1977;36:1760-1765

59. Zhang X, Scicli GA, Xu X, Nasjletti A, Hintze TH. Role of endothelial kinins in control of coronary nitric oxide production. Hypertension. 1997;30:1105-1111

60. Vanhoutte PM. [endothelial dysfunction and coronary heart disease. Interaction of endothelium and thrombocytes]. Schweiz Rundsch Med Prax. 1993;82:1161-1166

61. Hornig B, Kohler C, Drexler H. Role of bradykinin in mediating vascular effects of angiotensin-converting enzyme inhibitors in humans. Circulation. 1997;95:11151118

62. Mancia G, Fagard R, Narkiewicz K, Redon J, Zanchetti A, Bohm M, et al. 2013 esh/esc guidelines for the management of arterial hypertension: The task force for the management of arterial hypertension of the european society of hypertension (esh) and of the european society of cardiology (esc). Eur Heart J. 2013

63. Anderson TJ, Elstein E, Haber H, Charbonneau F. Comparative study of aceinhibition, angiotensin ii antagonism, and calcium channel blockade on flowmediated vasodilation in patients with coronary disease (banff study). J Am Coll Cardiol. 2000;35:60-66

64. Mancini GB, Henry GC, Macaya C, O'Neill BJ, Pucillo AL, Carere RG, et al. Angiotensin-converting enzyme inhibition with quinapril improves endothelial vasomotor dysfunction in patients with coronary artery disease. The trend (trial on reversing endothelial dysfunction) study. Circulation. 1996;94:258-265

65. Schiffrin EL. Remodeling of resistance arteries in human hypertension: Effects of cilazapril, an angiotensin-i-converting enzyme inhibitor. Cardiology. 1995;86 Suppl $1: 16-22$ 
66. Rizzoni D, Muiesan ML, Porteri E, Castellano M, Zulli R, Bettoni G, et al. Effects of long-term antihypertensive treatment with lisinopril on resistance arteries in hypertensive patients with left ventricular hypertrophy. J Hypertens. 1997;15:197204

67. Antony I, Lerebours G, Nitenberg A. Angiotensin-converting enzyme inhibition restores flow-dependent and cold pressor test-induced dilations in coronary arteries of hypertensive patients. Circulation. 1996;94:3115-3122

68. Taddei S, Virdis A, Ghiadoni L, Mattei P, Salvetti A. Effects of angiotensin converting enzyme inhibition on endothelium-dependent vasodilatation in essential hypertensive patients. J Hypertens. 1998;16:447-456

69. Hirooka Y, Imaizumi T, Masaki H, Ando S, Harada S, Momohara M, Takeshita A. Captopril improves impaired endothelium-dependent vasodilation in hypertensive patients. Hypertension. 1992;20:175-180

70. Millgard J, Hagg A, Sarabi M, Lind L. Captopril, but not nifedipine, improves endothelium-dependent vasodilation in hypertensive patients. J Hum Hypertens. $1998 ; 12: 511-516$

71. Lyons D, Webster J, Benjamin N. The effect of antihypertensive therapy on responsiveness to local intra-arterial ng-monomethyl-l-arginine in patients with essential hypertension. J Hypertens. 1994;12:1047-1052

72. Ghiadoni L, Versari D, Magagna A, Kardasz I, Plantinga Y, Giannarelli C, et al. Ramipril dose-dependently increases nitric oxide availability in the radial artery of essential hypertension patients. J Hypertens. 2007;25:361-366

73. Higashi Y, Sasaki S, Nakagawa K, Ueda T, Yoshimizu A, Kurisu S, et al. A comparison of angiotensin-converting enzyme inhibitors, calcium antagonists, betablockers and diuretic agents on reactive hyperemia in patients with essential hypertension: A multicenter study. J Am Coll Cardiol. 2000;35:284-291

74. Kiowski W, Linder L, Nuesch R, Martina B. Effects of cilazapril on vascular structure and function in essential hypertension. Hypertension. 1996;27:371-376 
75. Creager MA, Roddy MA. Effect of captopril and enalapril on endothelial function in hypertensive patients. Hypertension. 1994;24:499-505

76. Schiffrin EL, Park JB, Intengan HD, Touyz RM. Correction of arterial structure and endothelial dysfunction in human essential hypertension by the angiotensin receptor antagonist losartan. Circulation. 2000;101:1653-1659

77. Ghiadoni L, Virdis A, Magagna A, Taddei S, Salvetti A. Effect of the angiotensin ii type 1 receptor blocker candesartan on endothelial function in patients with essential hypertension. Hypertension. 2000;35:501-506

78. Tzemos N, Lim PO, MacDonald TM. Valsartan improves endothelial dysfunction in hypertension: A randomized, double-blind study. Cardiovasc Ther. 2009;27:151-158

79. Klingbeil AU, John S, Schneider MP, Jacobi J, Handrock R, Schmieder RE. Effect of at1 receptor blockade on endothelial function in essential hypertension. Am $J$ Hypertens. 2003;16:123-128

80. Suzuki R, Fukuda N, Katakawa M, Tsunemi A, Tahira Y, Matsumoto T, et al. Effects of an angiotensin ii receptor blocker on the impaired function of endothelial progenitor cells in patients with essential hypertension. Am J Hypertens. $2014 ; 27: 695-701$

81. Kerth PA, Vanhoutte PM. Effects of perindoprilat on endothelium-dependent relaxations and contractions in isolated blood vessels. Am J Hypertens. 1991;4:226S$234 \mathrm{~S}$

82. Ceconi C, Fox KM, Remme WJ, Simoons ML, Bertrand M, Parrinello G, et al. Ace inhibition with perindopril and endothelial function. Results of a substudy of the europa study: Pertinent. Cardiovasc Res. 2007;73:237-246

83. Yavuz D, Koc M, Toprak A, Akpinar I, Velioglu A, Deyneli O, et al. Effects of ace inhibition and at1-receptor antagonism on endothelial function and insulin sensitivity in essential hypertensive patients. J Renin Angiotensin Aldosterone Syst. 2003;4:197203 
84. Koh KK, Han SH, Chung WJ, Ahn JY, Jin DK, Kim HS, et al. Comparison of effects of losartan, irbesartan, and candesartan on flow-mediated brachial artery dilation and on inflammatory and thrombolytic markers in patients with systemic hypertension. Am J Cardiol. 2004;93:1432-1435, A1410

85. Morimoto S, Yano Y, Maki K, Sawada K. Renal and vascular protective effects of telmisartan in patients with essential hypertension. Hypertens Res. 2006;29:567-572

86. Yilmaz MI, Carrero JJ, Martin-Ventura JL, Sonmez A, Saglam M, Celik T, et al. Combined therapy with renin-angiotensin system and calcium channel blockers in type 2 diabetic hypertensive patients with proteinuria: Effects on soluble tweak, ptx3, and flow-mediated dilation. Clin J Am Soc Nephrol. 2010;5:1174-1181

87. Takiguchi S, Ayaori M, Uto-Kondo H, Iizuka M, Sasaki M, Komatsu T, et al. Olmesartan improves endothelial function in hypertensive patients: Link with extracellular superoxide dismutase. Hypertens Res. 2011;34:686-692

88. Farquharson CA, Struthers AD. Spironolactone increases nitric oxide bioactivity, improves endothelial vasodilator dysfunction, and suppresses vascular angiotensin i/angiotensin ii conversion in patients with chronic heart failure. Circulation. $2000 ; 101: 594-597$

89. Ullian ME. The role of corticosteriods in the regulation of vascular tone. Cardiovasc Res. 1999;41:55-64

90. Taddei S, Mattei P, Virdis A, Sudano I, Ghiadoni L, Salvetti A. Forearm vasodilation in response to acetylcholine is increased by potassium in essential hypertensive patients. J Hypertens Suppl. 1993;11:S144-145

91. Blanco-Rivero J, Cachofeiro V, Lahera V, Aras-Lopez R, Marquez-Rodas I, Salaices M, et al. Participation of prostacyclin in endothelial dysfunction induced by aldosterone in normotensive and hypertensive rats. Hypertension. 2005;46:107-112

92. Garnier A, Bendall JK, Fuchs S, Escoubet B, Rochais F, Hoerter J, et al. Cardiac specific increase in aldosterone production induces coronary dysfunction in aldosterone synthase-transgenic mice. Circulation. 2004;110:1819-1825 
93. Kobayashi N, Yoshida K, Nakano S, Ohno T, Honda T, Tsubokou Y, Matsuoka H. Cardioprotective mechanisms of eplerenone on cardiac performance and remodeling in failing rat hearts. Hypertension. 2006;47:671-679

94. Nakamura T, Fukuda M, Kataoka K, Nako H, Tokutomi Y, Dong YF, et al. Eplerenone potentiates protective effects of amlodipine against cardiovascular injury in salt-sensitive hypertensive rats. Hypertens Res. 2011;34:817-824

95. Savoia C, Touyz RM, Amiri F, Schiffrin EL. Selective mineralocorticoid receptor blocker eplerenone reduces resistance artery stiffness in hypertensive patients. Hypertension. 2008;51:432-439

96. Yamanari H, Nakamura K, Miura D, Yamanari S, Ohe T. Spironolactone and chlorthalidone in uncontrolled elderly hypertensive patients treated with calcium antagonists and angiotensin ii receptor-blocker: Effects on endothelial function, inflammation, and oxidative stress. Clin Exp Hypertens. 2009;31:585-594

97. Fujimura N, Noma K, Hata T, Soga J, Hidaka T, Idei N, et al. Mineralocorticoid receptor blocker eplerenone improves endothelial function and inhibits rho-associated kinase activity in patients with hypertension. Clin Pharmacol Ther. 2012;91:289-297

98. Rossi R, Nuzzo A, Iaccarino D, Lattanzi A, Origliani G, Monopoli DE, Modena MG. Effects of antihypertensive treatment on endothelial function in postmenopausal hypertensive women. A significant role for aldosterone inhibition. $J$ Renin Angiotensin Aldosterone Syst. 2011;12:446-455

99. Virdis A, Ghiadoni L, Qasem AA, Lorenzini G, Duranti E, Cartoni G, et al. Effect of aliskiren treatment on endothelium-dependent vasodilation and aortic stiffness in essential hypertensive patients. Eur Heart J. 2012;33:1530-1538

100. Dorresteijn JA, Schrover IM, Visseren FL, Scheffer PG, Oey PL, Danser AH, Spiering W. Differential effects of renin-angiotensin-aldosterone system inhibition, sympathoinhibition and diuretic therapy on endothelial function and blood pressure in obesity-related hypertension: A double-blind, placebo-controlled cross-over trial. $J$ Hypertens. 2012 
101. Perticone F, Ceravolo R, Maio R, Ventura G, Iacopino S, Cuda G, et al. Calcium antagonist isradipine improves abnormal endothelium-dependent vasodilation in never treated hypertensive patients. Cardiovasc Res. 1999;41:299-306

102. Taddei S, Virdis A, Ghiadoni L, Uleri S, Magagna A, Salvetti A. Lacidipine restores endothelium-dependent vasodilation in essential hypertensive patients. Hypertension. 1997;30:1606-1612

103. Schiffrin EL, Deng LY. Structure and function of resistance arteries of hypertensive patients treated with a beta-blocker or a calcium channel antagonist. J Hypertens. $1996 ; 14: 1247-1255$

104. Muiesan ML, Salvetti M, Belotti E, Paini A, Rosei CA, Aggiusti C, et al. Effects of barnidipine in comparison with hydrochlorothiazide on endothelial function, as assessed by flow mediated vasodilatation in hypertensive patients. Blood Press. $2011 ; 20: 244-251$

105. Frielingsdorf J, Seiler C, Kaufmann P, Vassalli G, Suter T, Hess OM. Normalization of abnormal coronary vasomotion by calcium antagonists in patients with hypertension. Circulation. 1996;93:1380-1387

106. Rubanyi GM, Vanhoutte PM. Calcium and activation of the release of endotheliumderived relaxing factor. Ann N Y Acad Sci. 1988;522:226-233

107. Cardillo C, Kilcoyne CM, Waclawiw M, Cannon RO, 3rd, Panza JA. Role of endothelin in the increased vascular tone of patients with essential hypertension. Hypertension. 1999;33:753-758

108. Cardillo C, Campia U, Kilcoyne CM, Bryant MB, Panza JA. Improved endotheliumdependent vasodilation after blockade of endothelin receptors in patients with essential hypertension. Circulation. 2002;105:452-456

109. Tiryaki O, Usalan C, Buyukhatipoglu H, Sayiner ZA, Kilisli H. Effects of lisinopril, irbesartan, and amlodipine on the thrombogenic variables in the early and late stages of the treatment in hypertensive patients. Clin Exp Hypertens. 2012;34:145-152 
110. Schiffrin EL, Sventek P, Li JS, Turgeon A, Reudelhuber T. Antihypertensive effect of an endothelin receptor antagonist in doca-salt spontaneously hypertensive rats. $\mathrm{Br}$ J Pharmacol. 1995;115:1377-1381

111. Muiesan ML, Salvetti M, Monteduro C, Rizzoni D, Zulli R, Corbellini C, et al. Effect of treatment on flow-dependent vasodilation of the brachial artery in essential hypertension. Hypertension. 1999;33:575-580

112. Schiffrin EL, Deng LY. Comparison of effects of angiotensin i-converting enzyme inhibition and beta-blockade for 2 years on function of small arteries from hypertensive patients. Hypertension. 1995;25:699-703

113. Zhou MS, Schulman IH, Jaimes EA, Raij L. Thiazide diuretics, endothelial function, and vascular oxidative stress. J Hypertens. 2008;26:494-500

114. Gao YS, Nagao T, Bond RA, Janssens WJ, Vanhoutte PM. Nebivolol induces endothelium-dependent relaxations of canine coronary arteries. $J$ Cardiovasc Pharmacol. 1991;17:964-969

115. Cockcroft JR, Chowienczyk PJ, Brett SE, Chen CP, Dupont AG, Van Nueten L, et al. Nebivolol vasodilates human forearm vasculature: Evidence for an 1-arginine/nodependent mechanism. J Pharmacol Exp Ther. 1995;274:1067-1071

116. Dawes M, Brett SE, Chowienczyk PJ, Mant TG, Ritter JM. The vasodilator action of nebivolol in forearm vasculature of subjects with essential hypertension. $\mathrm{Br} J \mathrm{Clin}$ Pharmacol. 1999;48:460-463

117. Fargin A, Raymond JR, Lohse MJ, Kobilka BK, Caron MG, Lefkowitz RJ. The genomic clone g-21 which resembles a beta-adrenergic receptor sequence encodes the 5-ht1a receptor. Nature. 1988;335:358-360

118. Brehm BR, Bertsch D, von Fallois J, Wolf SC. Beta-blockers of the third generation inhibit endothelin-1 liberation, mrna production and proliferation of human coronary smooth muscle and endothelial cells. J Cardiovasc Pharmacol. 2000;36:S401-403 
119. Troost R, Schwedhelm E, Rojczyk S, Tsikas D, Frolich JC. Nebivolol decreases systemic oxidative stress in healthy volunteers. Br J Clin Pharmacol. 2000;50:377379

120. Tzemos N, Lim PO, MacDonald TM. Nebivolol reverses endothelial dysfunction in essential hypertension: A randomized, double-blind, crossover study. Circulation. 2001;104:511-514

121. Pasini AF, Garbin U, Stranieri C, Boccioletti V, Mozzini C, Manfro S, et al. Nebivolol treatment reduces serum levels of asymmetric dimethylarginine and improves endothelial dysfunction in essential hypertensive patients. Am J Hypertens. $2008 ; 21: 1251-1257$

122. Korkmaz H, Karaca I, Koc M, Onalan O, Yilmaz M, Bilen MN. Early effects of treatment with nebivolol and quinapril on endothelial function in patients with hypertension. Endothelium. 2008;15:149-155

123. Vitale C, Marazzi G, Iellamo F, Spoletini I, Dall'Armi V, Fini M, Volterrani M. Effects of nebivolol or irbesartan in combination with hydrochlorothiazide on vascular functions in newly-diagnosed hypertensive patients: The ninfe (nebivololo, irbesartan nella funzione endoteliale) study. Int J Cardiol. 2012;155:279-284

124. Peller M, Ozieranski K, Balsam P, Grabowski M, Filipiak KJ, Opolski G. Influence of beta-blockers on endothelial function: A meta-analysis of randomized controlled trials. Cardiol J. 2015;22:708-716

125. Vinereanu D, Dulgheru R, Magda S, Dragoi Galrinho R, Florescu M, Cinteza M, et al. The effect of indapamide versus hydrochlorothiazide on ventricular and arterial function in patients with hypertension and diabetes: Results of a randomized trial. Am Heart J. 2014;168:446-456

126. Joannides R, Bellien J, Thurlure C, Iacob M, Abeel M, Thuillez C. Fixed combination of perindopril and indapamide at low dose improves endothelial function in essential hypertensive patients after acute administration. Am J Hypertens. 2008;21:679-684 
127. Dell'Omo G, Penno G, Del Prato S, Pedrinelli R. Chlorthalidone improves endothelial-mediated vascular responses in hypertension complicated by nondiabetic metabolic syndrome. J Cardiovasc Pharmacol Ther. 2005;10:265-272

128. Yanagisawa M, Kurihara H, Kimura S, Goto K, Masaki T. A novel peptide vasoconstrictor, endothelin, is produced by vascular endothelium and modulates smooth muscle ca2+ channels. J Hypertens Suppl. 1988;6:S188-191

129. Haynes WG, Strachan FE, Webb DJ. Endothelin eta and etb receptors cause vasoconstriction of human resistance and capacitance vessels in vivo. Circulation. $1995 ; 92: 357-363$

130. Imai T, Hirata Y, Emori T, Yanagisawa M, Masaki T, Marumo F. Induction of endothelin-1 gene by angiotensin and vasopressin in endothelial cells. Hypertension. $1992 ; 19: 753-757$

131. d'Uscio LV, Barton M, Shaw S, Moreau P, Luscher TF. Structure and function of small arteries in salt-induced hypertension: Effects of chronic endothelin-subtype-areceptor blockade. Hypertension. 1997;30:905-911

132. Kohno M, Yasunari K, Murakawa K, Yokokawa K, Horio T, Fukui T, Takeda T. Plasma immunoreactive endothelin in essential hypertension. Am J Med. $1990 ; 88: 614-618$

133. Russell FD, Skepper JN, Davenport AP. Endothelin peptide and converting enzymes in human endothelium. J Cardiovasc Pharmacol. 1998;31 Suppl 1:S19-21

134. Wagner OF, Christ G, Wojta J, Vierhapper H, Parzer S, Nowotny PJ, et al. Polar secretion of endothelin-1 by cultured endothelial cells. J Biol Chem. 1992;267:1606616068

135. Schiffrin EL, Deng LY, Sventek P, Day R. Enhanced expression of endothelin-1 gene in resistance arteries in severe human essential hypertension. $J$ Hypertens. $1997 ; 15: 57-63$ 
136. Ergul S, Parish DC, Puett D, Ergul A. Racial differences in plasma endothelin-1 concentrations in individuals with essential hypertension. Hypertension. $1996 ; 28: 652-655$

137. Krum H, Viskoper RJ, Lacourciere Y, Budde M, Charlon V. The effect of an endothelin-receptor antagonist, bosentan, on blood pressure in patients with essential hypertension. Bosentan hypertension investigators. N Engl J Med. 1998;338:784-790

138. Reriani M, Raichlin E, Prasad A, Mathew V, Pumper GM, Nelson RE, et al. Longterm administration of endothelin receptor antagonist improves coronary endothelial function in patients with early atherosclerosis. Circulation. 2010;122:958-966 
